International Journal of Business Management and Economic Review

Vol. 4, No. 01; 2021

ISSN: 2581-4664

\title{
THE EFFECT OF REWARD INTRINSIC, EMPLOYEE PERCEIVED AND TRAINING EFFECTIVENESS ON WORK MOTIVATION AND ITS IMPACT ON THE PERFORMANCE OF EMPLOYEES OF THE ACEH REGIONAL SECRETARIAT OFFICE
}

\author{
Bustami, Mukhlis, Amri \\ Magister Manajemen, Universitas Syiah Kuala, Indonesia \\ http://doi.org/10.35409/IJBMER.2021.3228
}

\begin{abstract}
This study aims to examine the effect of reward intrinsic, employee perceived, and training effectiveness on employee motivation and its impact on employee performance at the Aceh Regional Secretariat office (Setda Aceh). The population is 621 employees who work at the Bureau within the Setda Aceh. The research sample was taken by proportional sampling. After using the solvin formula, a sample of 151 people was obtained. This research model was tested by Structural Equation Modeling (SEM). The research result proved that reward intrinsic significantly affected employee work motivation, employee perceived significantly affected employee work motivation, training effectiveness significantly affected employee work motivation, reward intrinsic significantly affected employee performance, employee perceived significantly affected employee performance, significant training effectiveness affected employee performance, reward Instrinsic significantly affected employee performance mediated by employee work motivation, employee perceived significantly affected employee performance mediated by employee work motivation, and training effectiveness significantly affected employee performance mediated by employee work motivation. The motivation was proven to act as a partial mediator because it can be the path of choice by predictor variables to improve employee performance. This model contributes to the academic realm, where the theory of causality has previously been proven and is appropriate in this study. The novelty of this research lies in the combination of previous theories of causality so that it integrates into one model, and uses objects that have never been used before following the model. Theory update is part of research development. Therefore, for future research, further researchers are expected to be able to add other variables such as moderating variables in the form of gender or income or even mediating variables such as human capital. This proven model also contributes to practitioners, especially in the Setda Aceh, where this model can be applied to the implementation of strategies for improving performance in the Setda Aceh. Reward intrinsic, employee perceived, and training effectiveness are predictors of driving something that will happen to motivation so that it can improve the performance of Setda Aceh employees.
\end{abstract}

Keyword: Reward intrinsics, Employee Perceived, Training Effectiveness, Employee Motivation, and Employee Performance. 


\section{International Journal of Business Management and Economic Review}

Vol. 4, No. 01; 2021

ISSN: 2581-4664

\section{INTRODUCTION}

Aceh Regional Secretariat Office (Setda Aceh), which is an institution that functions as the secretariat for the Government of Aceh Province, Indonesia (under the Governor and Deputy Governor of Aceh Province). In its organizational structure, the Setda Aceh has 8 (eight) Bureaus, namely the Administration and Development Bureau, the Legal Bureau, the Public Relations Bureau, the Privileges and People's Welfare Bureau, the Organization Bureau, the Bureau, the Economy, the Government Administration Bureau, and the General Blue and Protocol. Based on employee data obtained from the Setda Aceh, it is known that the placement of employee positions by comparing between the bureaus it has, it is known that the General and Protocol Bureau has a relatively large number of employees compared to other bureaus within the Setda Aceh. This happened because the duties and functions of the General and Protocol Bureau were broader when compared to other bureaus.

To improve employee performance, in 2019 the Government has issued a Government Regulation (PP) No. 30 Tahun 2019 concerning the work assessment of Civil Servants. This PP regulates, among others, the Substance of PNS Performance Appraisal which consists of an assessment of work behavior and an assessment of PNS Performance. Apart from the PP, regional leaders have implemented various regulations to improve employee performance, one of which is through e-performance. Every employee is required to report their performance through the application every day and must be evaluated by the leadership no later than 2 days after the reporting is done.

The birth of e-performance is because there are still many employees who work or carry out tasks that are not following their functions and are not following the workload of each employee. The phenomenon of low employee performance can be seen from the Setda Aceh LAKIP, which shows that work realization figures are still far from the targeted figures. Another phenomenon that occurred in the Setda Aceh was the low work motivation of employees in carrying out their duties and responsibilities as employees, employees were still not able to give all their energy and mental abilities for organizational progress. Low employee motivation results in decreased employee performance, especially in providing services to the community.

Low work motivation and employee performance are influenced by several factors, including reward intrinsic in the form of rewards received by employees, positive employee attitudes, and rotation and promotion. Then there is something that can be felt by employees (employee perceived) to the work contribution that employees have given to the organization as well as the extra effort made by employees to the work done. Meanwhile, training conducted by the organization also influences on improving employee performance and employee motivation.

Appreciation is one of the factors to increase work passion, the higher the work motivation will increase work motivation or a decreased work passion will affect the decrease in motivation Meanwhile, Employee perceived is the employee's perception of the organization regarding the extent to which the organization appreciates their contribution and cares about their welfare. Employee perceived also produces a response in the form of employee engagement level. Employees who have strong ties to their organization feel comfortable and like the things around them, both with their work environment and role responsibilities so that these employees can improve work performance to achieve the goals of the organization. 


\section{International Journal of Business Management and Economic Review}

Vol. 4, No. 01; 2021

ISSN: 2581-4664

\section{LITERATURE STUDY}

\section{Employee Performance}

Performance is tangible behavior that is shown by everyone as a work achievement achieved by an employee following his role in the organization(Gaol, 2014).Employee performance is the result or the entire level of success when carrying out a task during a certain period, compared to other possibilities such as standard output/outcome, goals, objectives, and other predetermined criteria(Nuraini, 2014).

(Mathis \& Jackson, 2011) stated that performance is the output produced by a function or individual in a particular job or profession. Performance, which is often referred to as a work achievement, is the result of work in terms of quantity and quality achieved by a person in carrying out tasks according to the responsibilities given at a certain time. Employee performance can be measured using indicators as disclosed by(Mathis \& Jackson, 2011)as follows: (1) quality of work, (2) quantity, (3) timeliness, (4) effectiveness, (5) independence, and (6) work commitment.

\section{Work motivation}

(Hasibuan, 2014)mentions that motivation is given to humans, especially to subordinates or followers. While(Robbins \& Judge, 2017)stated motivation is a potential power that is in a person, which can be developed by themselves or developed by some external forces that exist. The factors that influence work motivation are (1) knowledge management, (2) organizational learning, (3) job satisfaction, (4) reward intrinsic, (5) employee perceived, and (6) training effectiveness. Motivation indicators use theory(Maslow, 1943)in(Robbins \& Judge, 2017)classify human needs into five sequentially, namely: (1) Physiological Needs, (2) The need for security, (3) the need for a sense of belonging and being loved, (4) the need for selfrecognition, and (5) the need for self-actualization.

\section{Reward Intrinsic}

Reward according to(Edirisooriya, 2014)is the benefit received for performing the task. It is a positive stimulus or incentive that can be presented in the process of reinforcing the behavior. The considerations in work arrangements are called employee benefits. Reward benefits are a leadership program to use and supplement cash compensation received by employees.(Nawawi, 2011)argued that rewards for organizations or companies mean rewards and rewards to workers who have contributed to realizing their goals, through activities called work.(Yuniarsih \& Suwatno, 2016)said that employee reward means all forms of pay or rewards that flow to employees or arise from their employment.

According to(Edirisooriya, 2014)rewardintrinsicis a reward that is not real, in this case in the form of psychological benefits. Reward intrinsic indicators such as (1) rewards, (2) finding new challenges, (3) positive attitudes, (4) caring from superiors, and (5) job rotation.

\section{Employee Perceived}

Employee perceived is the degree to which employees believe their contributions and welfare are appreciated by the organization(Robbins \& Judge, 2017). Organizations generally provide positive forms of support to employees, for example by giving approval, respect, fair treatment, 


\section{International Journal of Business Management and Economic Review}

Vol. 4, No. 01; 2021

ISSN: 2581-4664

salary, promotion, voting rights, access to information, and other assistance that can support the implementation of work and welfare.(Rakhmat, 1999)stated perception is an observation about objects, events, or relationships obtained by inferring information and interpreting messages.

Employee perceived can be measured using indicators as disclosed by(Robbins \& Judge, 2017)namely: 1) The organization appreciates employee contributions; 2) The organization appreciates the extra effort employees have put in; 3) The organization will pay attention to all complaints from employees, 4) The organization cares about the welfare of employees; 5) The organization will notify employees if they are not doing their job well; 6) The organization is concerned with general satisfaction with the work of employees; 7) The organization shows great concern for employees, and; 8) The organization is proud of its employees' success at work.

\section{Training Effectiveness}

Based on Article 1 paragraph 9 of Law no. 13 of 2003 of Manpower, training is the whole activity to provide, obtain, improve, and develop work competence, productivity, discipline, attitudes, and work ethic at certain skill and expertise levels according to the level and qualification of the position or job.(Mathis \& Jackson, 2011)mentioned Training is a process where people achieve certain abilities to help achieve organizational goals. (Dessler, 2003)cited training as the process of teaching new or existing employees the basic skills they need to carry out their jobs. (Simamora, 2004)believed that training has the aim of improving work and updating skills. According to(Mangkunegara, 2013) there are four indicators or criteria that can be used as guidelines for measuring the effectiveness of training, namely: (1) opinion criteria; (2) learning criteria; (3) behavioral criteria; and (4) outcome criteria.

\section{Research paradigm}

Based on the discussion of the problems and research literature, the researcher formulates the research paradigm and hypothesis as follows.

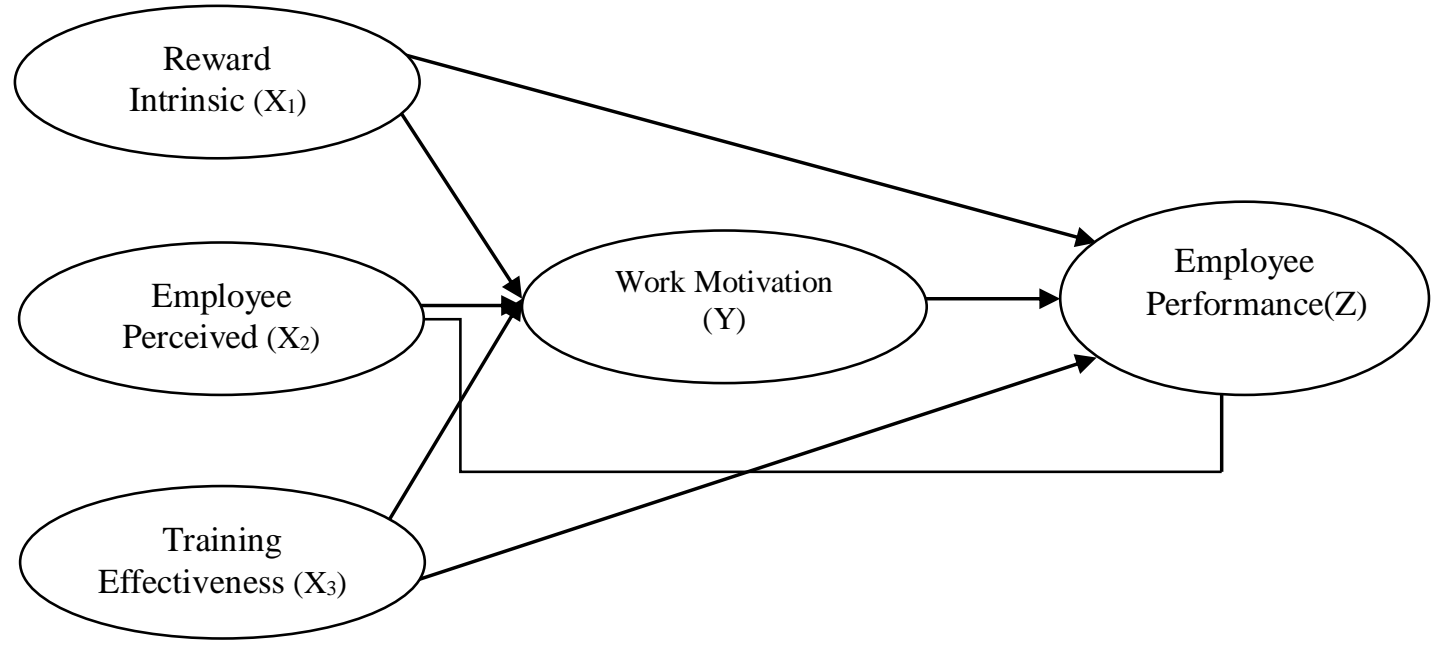

Figure 1. Research Paradigm

H1: Reward intrinsic significantly affected the work motivation of the Setda Aceh employees. $\mathrm{H} 2$ : employee perceived significantly affected the work motivation of the Setda Aceh 


\section{International Journal of Business Management and Economic Review}

Vol. 4, No. 01; 2021

ISSN: 2581-4664

employees.

H3: training effectiveness significantly affected the work motivation of the Setda Aceh employees.

H4: Reward intrinsic significantly affected the performance of Setda Aceh employees.

H5: employee perceived significantly affected the performance of Setda Aceh employees.

H6: training effectiveness significantly affected the performance of Setda Aceh employees.

H7: Employee work motivation significantly affected the performance of Setda Aceh employees.

H8: Reward intrinsic significantly affected employee performance mediated by the work motivation of the Setda Aceh employees.

H9: employee perceived significant affected on employee performance mediated by the work motivation of the Setda Aceh employees.

H10: training effectiveness significantly affected employee performance mediated by the work motivation of the Setda Aceh employees.

\section{RESEARCH METHODS}

This study used an object, namely the Setda Aceh. The variables in the study were anreward intrinsic, employee perceived, training effectiveness, work motivation, and employee performance. The population was all employees who work at the Setda Aceh, as many as 611 people. Sample determined by proportional sampling. The reason for using the proportional sampling method was because the population had members/elements that were not homogeneous and proportionally stratified(Arikunto, 2014)explained that the greater the number of samples or the closer to the population, the smaller the chances of errors occurring in generalizing, and vice versa. The number of samples is determined using the Slovin formula(H. Umar, 2008), as follows:

$$
\begin{aligned}
& n=\frac{N}{1+N e^{2}} \\
& n=\frac{611}{1+611(7 \%)^{2}} \\
& n=\frac{611}{1+611(0,007)} \\
& n=\frac{611}{1+3,04} \\
& n=\frac{611}{4,04}=151,2=\text { fulfilled to be } 151 \text { people }
\end{aligned}
$$

Based on the work unit, the population and sample size in the Setda Aceh is shown in the following table: 


\section{International Journal of Business Management and Economic Review}

Vol. 4, No. 01; 2021

ISSN: 2581-4664

Table 1. Research Sample

\begin{tabular}{|c|l|c|c|}
\hline No. & \multicolumn{1}{|c|}{ Work unit } & Population & sample \\
\hline 1. & Administration and Development Bureau & 39 & $\frac{39}{611} \times 151=10$ \\
\hline 2. & Legal Bureau & 37 & $\frac{37}{611} \times 151=9$ \\
\hline 3. & Public Relations Bureau & 26 & $\frac{26}{611} \times 151=6$ \\
\hline 4. & Privileges and Welfare Bureau & 71 & $\frac{71}{611} \times 151=17$ \\
\hline 5. & Organization Bureau & 63 & $\frac{63}{611} \times 151=16$ \\
\hline 6. & Bureau of the Economy & 46 & $\frac{46}{611} \times 151=11$ \\
\hline 7. & Administration Bureau & 44 & $\frac{44}{611} \times 151=11$ \\
\hline 8. & General Bureau and Protocol & 285 & $\frac{285}{611} \times 151=71$ \\
\hline Total & & 611 & 151 \\
\hline
\end{tabular}

Source: Setda Aceh, (2020)

Data were collected using a questionnaire method, where the list of questions asked provides answers using a Likert scale. The data were analyzed using the Structural Equation Modeling (SEM) technique.(Ferdinand, 2014).SEM can include latent variables in the analysis(Ghozali, 2018).Then mathematically the causality relationship between the constructs in the study can be stated as follows:

$\eta=\gamma 1.1 \xi 1+\gamma 1.2 \xi 2+\gamma 1.3 \xi 3+\zeta 1$

$\eta=\gamma 2.1 \xi 1+\gamma 2.2 \xi 2+\gamma 2.3 \xi 3+\beta 21 \eta 2+\zeta 2$

or:

work motivation $\quad=\gamma 11$ reward intrinsic $+\gamma 12$ employee perceived $+\gamma 13$ training effectiveness $+\zeta 1$

Employee Performance $=\gamma 21$ reward intrinsic $+\gamma 12$ employee perceived $+\gamma 13$ training effectiveness $+\beta 21$ work motivation $+\zeta 2$

Information:

$\gamma$ :The magnitude of the coefficient of influence from exogenous to endogenous variables

$\beta$ :The magnitude of the coefficient of influence from endogenous to endogenous

$\zeta:$ The magnitude of the vector error (error)

The mediation hypothesis was tested with a Sobel test formula(Sobel, 1982). This single test function is to test the significance of the indirect effect of the independent variable (X) on the dependent variable $(\mathrm{Z})$ through the mediating variable $(\mathrm{Y})$.

\section{RESULT AND DISCUSSION}




\section{International Journal of Business Management and Economic Review}

Vol. 4, No. 01; 2021

ISSN: 2581-4664

The structural model analysis explaining the effect test between variables is presented in the following path diagram:

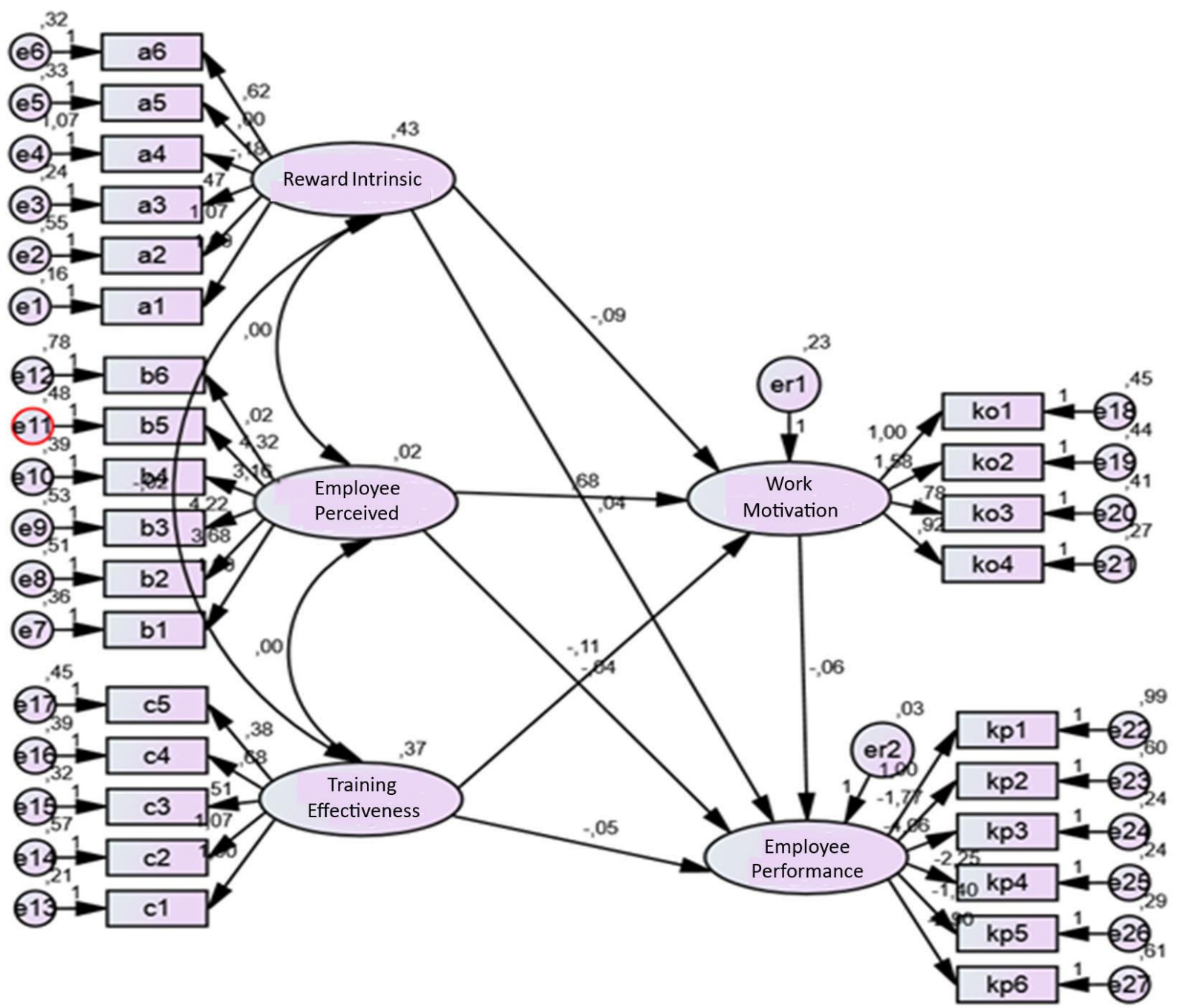

Figure 2. Structural Test Results

The full model test results for testing the direct effect hypothesis after fulfilling the SEM assumptions are more clearly shown in the following table:

Table 2. Hypothesis Test Results

\begin{tabular}{|l|c|l|c|c|c|c|}
\hline \multicolumn{1}{|c|}{ Endogenous } & & \multicolumn{1}{|c|}{ Exogenous } & Estimate & S.E. & C.R. & P \\
\hline Work Motivation & $<---$ & Reward Intrinsic & 0.542 & 0.078 & 6.949 & $* * *$ \\
\hline Work Motivation & $<---$ & Employee Perceived & 0.925 & 0.159 & 5.818 & $* * *$ \\
\hline Work Motivation & $<---$ & Training Effectiveness & 0.652 & 0.097 & 6.722 & $* * *$ \\
\hline Employee Performance & $<---$ & Work Motivation & 0.430 & 0.143 & 3.007 & $* * *$ \\
\hline
\end{tabular}


International Journal of Business Management and Economic Review

Vol. 4, No. 01; 2021

ISSN: 2581-4664

\begin{tabular}{|l|c|l|c|c|c|c|}
\hline \hline Employee Performance & $<---$ & Reward Intrinsic & 0.126 & 0.049 & 2.571 & $* * *$ \\
\hline Employee Performance & $<---$ & Employee Perceived & 0.386 & 0.158 & 2.443 & $* * *$ \\
\hline Employee Performance & $<---$ & Training Effectiveness & 0.451 & 0.142 & 3.176 & $* * *$ \\
\hline
\end{tabular}

Source: Primary data processed (processed)

By looking at the test results in table 2, the analysis can be explained as follows:

1. H1: Testing the effect of reward intrinsics on the work motivation of the Setda Aceh employees resulted in a CR value of 6.949 and a significant p-value of 0.000 . The value obtained can be stated as being following the requirements for receiving H1, namely with a CR value of 6.949> 1.97 and a p-value $<0.05$. So it can be explained that reward intrinsic significantly affected the work motivation of employees at the Setda Aceh. These results explain that the higher reward intrinsic received by employees will have a positive influence on increasing work motivation because of the desire from within the employee to work better. The results of this test are proven to be consistent with the results of previous research tested by(Munir, Lodhi, Sabir, \& Khan, 2016), (Danish, Khan, Shahid, Raza, \& Humayon, 2015), (A. Umar, 2015), (Febrianti, Musadieq, \& Prasetya, 2014).

2. H2: Testing the Effect of Employee Perceived on Work Motivation of the Setda Aceh employees resulted in a $\mathrm{CR}$ value of 5.818 and a significant $\mathrm{p}$-value of 0.000 . The value obtained can be stated as being following the requirements for receiving $\mathrm{H} 2$, namely with a CR value of 5.818> 1.97 and a p-value of 0.05 . So it is evident that employee perceived significantly affected the work motivation of employees at the Setda Aceh. These results explain that the better employee perceived will have an effect on increasing work motivation because employees have felt things that are appropriate/good/satisfied while in the organization. The results of this test are proven to be consistent with the results of previous research tested by(Sunardi, Adam, \& Putra, 2020) dan(Susanty \& Miradipta, 2013)which revealed that employee perceived influenced on increasing employee motivation.

3. H3: Testing the Effect of Training Effectiveness on the work motivation of the Setda Aceh employees resulted in a CR value of 6.722 and a significant $p$-value of 0.000 . The value obtained can be stated that it is following the requirements to receive $\mathrm{H} 3$, namely with a $\mathrm{CR}$ value of $6.722>1.97$ and a p-value $<0.05$. So it can be explained that training effectiveness significantly affected the work motivation of the Setda Aceh employees. These results explain that the existence of a high level of effectiveness will have a positive impact on increasing employee motivation. The results of this test are proven to be consistent with the results of previous research tested by(Özkeser, 2019),(Gusdiana, Ma'aruf, \& Sulaiman, 2015), and(Pushpakumari, 2008)that revealed the training effectiveness felt by employees influenced work motivation.

4. H4: Testing the effect of reward intrinsics on employee performance of the Setda Aceh resulted in a CR value of 2.571 and a significant $p$-value of 0.000 . The value obtained can be declared following the requirements for receiving $\mathrm{H} 4$, namely with a $\mathrm{CR}$ value of $2.571>1.97$ and a p-value $<0.05$. So it is evident that reward intrinsic significantly affected the performance of the Setda Aceh employees. This evidence explains that the better the reward intrinsic obtained by employees can have a positive effect on improving employee 
Vol. 4, No. 01; 2021

ISSN: 2581-4664

performance. The results of this test are proven to be consistent with the results of previous research tested by(Munir et al., 2016),(Danish et al., 2015), (Januar \& Handayani, 2015), (Edirisooriya, 2014), and(Komalasari, Nasih, \& Prasetio, 2009)that revealedthereward intrinsic had a positive effect in improving employee performance.

5. H5: Testing the Effect of Employee Perceived on Employee Performance of the Setda Aceh resulted in a CR value of 2.443 and a significant p-value of 0.000 . The value obtained can be stated as being following the requirements for receiving $\mathrm{H} 5$, namely with a CR value of 2.443> 1.97 and a p-value of $<0.05$. So it is evident that employee perceived significantly affectedthe performance of Setda Aceh employees. Employees were perceived to have an impact on employee knowledge and career development in the future. The results of this test are proven to be consistent with the results of previous research tested by(Bušatlić \& Music, 2018), (Ariarni \& Afrianty, 2017), and(Nzuve \& Njambi, 2015)that found the employee perceived influenced on employee performance, because of the positive perceived shown by employees in carrying out their duties and obligations.

6. H6: Testing the Effect of Training Effectiveness on Employee Performance of the Setda Aceh resulted in a CR value of 3.176 and a significant $p$-value of 0.000 . The value obtained can be stated that it is following the requirements to receive H6, namely with a CR value of $3.176>1.97$ and a p-value $<0.05$. So it is proven that training effectiveness significantly affected the performance of the Setda Aceh employees. Training effectiveness can be seen from the ability of employees to generate competitive ideas according to their function in the organizational structure and the ability of employees to be able to complete work according to the work standards given by the leadership. Based on the results of the evidence, it can also be explained that the training effectiveness felt by employees can have an impact on employee motivation, especially in improving employee performance in achieving the organizational goals of Setda Aceh.The results of this test are proven to be consistent with the results of previous research tested by(Guan \& Frenkel, 2019)(Rachmawati, 2016), (Mangkunegara \& Waris, 2015), and(Gusdiana et al., 2015)which resulted that training effectiveness affected improving employee performance.

7. H7: Testing the Effect of Work Motivation on Employee Performance of the Setda Aceh resulted in a CR value of 3.007 and a significant $p$-value of 0.000 . The value obtained can be declared following the requirements for receiving H7, namely with a $\mathrm{CR}$ value of 3.007> 1.97 and a $p$-value $<0.05$. So it is evident that work motivation significantly affected the performance of the Setda Aceh employees. The result of this evidence implies that the higher the level of satisfaction generated by the employees will have a good influence on improving the performance of the Setda Aceh employees. The results of this test are proven to be consistent with the results of previous research tested by(Basri \& Kadir, 2019)(Muchlis, Amri, \& Majid, 2017)and(Kurniawan, Lubis, \& Adam, 2012)that found the work motivation contributed to improving employee performance.

Furthermore, the mediation test is carried out as shown in the image below 
Vol. 4, No. 01; 2021

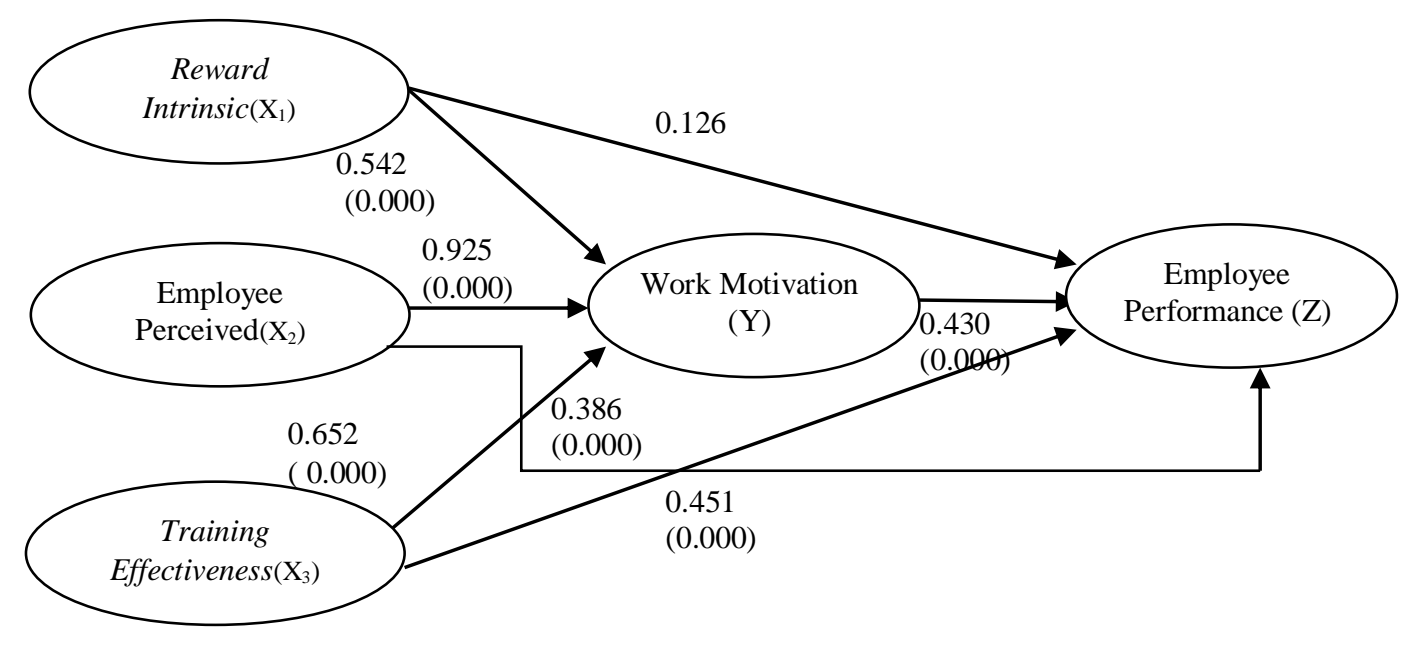

Figure 3. Influence Between Variables in the Flow Chart

Based on the results of the SEM test, the coefficients showing the direct and indirect effects can be seen in the following table:

Table 3 ,Direct Effect and Mediation Coefficients

\begin{tabular}{|c|l|c|c|c|}
\hline No & \multicolumn{1}{|c|}{ Description } & Direct & Mediation & Information \\
\hline 1. & $\begin{array}{l}\text { Influence of reward intrinsic on } \\
\text { employee performance }\end{array}$ & $\begin{array}{c}(0.126)^{2} \\
=0.016\end{array}$ & $\begin{array}{c}0.542 \times 0.430 \\
=0.233\end{array}$ & Direct<Indirect \\
\hline 2. & $\begin{array}{l}\text { The effect of employee perceived } \\
\text { on employee performance }\end{array}$ & $\begin{array}{c}(0.386)^{2} \\
=0.149\end{array}$ & $\begin{array}{c}0.925 \times 0.430 \\
=0.398\end{array}$ & Direct<Indirect \\
\hline 3. & $\begin{array}{l}\text { The effect of training } \\
\text { effectiveness on employee } \\
\text { performance }\end{array}$ & $\begin{array}{l}(0.451)^{2} \\
=0.203\end{array}$ & $\begin{array}{c}0.652 \times 0.430 \\
=0.280\end{array}$ & Direct<Indirect \\
\hline
\end{tabular}

Source: Primary Data, 2020 (processed).

By looking at the test results in table 3, the analysis can be explained as follows:

1. H8: Testing the indirect effect through Sobel testing between Reward intrinsics on Employee Performance Mediated by the work motivation of the Setda Aceh employees produced a $\mathrm{p}$-value of 0.000 , and also produced a coefficient value of 0.233 . This value proves that reward intrinsic had a significant indirect effect on employee performance mediated by the work motivation of the Setda Aceh employees. The results of this evidence imply that the higher the level of employee reward intrinsic will have an impact on 


\section{International Journal of Business Management and Economic Review}

Vol. 4, No. 01; 2021

ISSN: 2581-4664

improving employee performance mediated by the work motivation of the Setda Aceh employees.

2. H9: Testing the indirect effect through Sobel testing between Employee Perceived on Employee Performance Mediated by the work motivation of the Setda Aceh employees produced a p-value of 0.000 , and also produced a coefficient value of 0.398 . This value proves that employee perceived had a significant indirect effect on employee performance mediated by the work motivation of the Setda Aceh employees. The results of this evidence imply that the higher the employee's perceived level of employees will have an impact on improving employee performance through the satisfaction felt by Setda Aceh employees.

3. H10: Testing the indirect effect through Sobel testing between Training Effectiveness on Employee Performance Mediated by the work motivation of the Setda Aceh employees produced a p-value of 0.000 , and also produced a coefficient value of 0.280 . This value proves that training effectiveness had a significant indirect effect on employee performance mediated by the work motivation of the Setda Aceh employees. The results of this test imply that the better the training effectiveness applied by the leadership of each division will have an impact on improving employee performance through the satisfaction felt by the Setda Aceh employees.

\section{CONCLUSION}

The research result proved that reward intrinsic significantly affected employee work motivation, employee perceived significantly affected employee work motivation, training effectiveness significantly affected employee work motivation, reward intrinsic significantly affected employee performance, employee perceived significantly affected employee performance, significant training effectiveness affected employee performance, reward Instrinsic significantly affected employee performance mediated by employee work motivation, employee perceived significantly affected employee performance mediated by employee work motivation, and training effectiveness significantly affected employee performance mediated by employee work motivation. The motivation was proven to act as a partial mediator because it can be the path of choice by predictor variables to improve employee performance. This model contributes to the academic realm, where the theory of causality has previously been proven and is appropriate in this study. The novelty of this research lies in the combination of previous theories of causality so that it integrates into one model, and uses objects that have never been used before following the model. Theory update is part of research development. Therefore, for future research, further researchers are expected to be able to add other variables such as moderating variables in the form of gender or income or even mediating variables such as human capital. This proven model also contributes to practitioners, especially in the Setda Aceh, where this model can be applied to the implementation of strategies for improving performance in the Setda Aceh. Reward intrinsic, employee perceived, and training effectiveness are predictors of driving something that will happen to motivation so that it can improve the performance of Setda Aceh employees. 


\section{International Journal of Business Management and Economic Review}

Vol. 4, No. 01; 2021

ISSN: 2581-4664

\section{REFERENCES}

Ariarni, N., \& Afrianty, T. W. (2017). Pengaruh Perceived Organizational Support Terhadap Kinerja Karyawan Dengan Employee Engagement Sebagai Variabel Intervening (Studi Pada Karyawan PT. Pos Indonesia Kota Madiun). Jurnal Administrasi Bisnis (JAB), 50(4), 169-177.

Arikunto, S. (2014). Prosedur Penelitian suatu Pendekatan Praktik. Jakarta: Renika Cipta.

Basri, M., \& Kadir, A. (2019). Pengaruh Motivasi Kerja Dan Iklim Organisasi Terhadap Kinerja Pegawai Pada Lembaga Penjaminan Mutu Pendidikan Provinsi Sulawesi Tenggara. Journal Publicuho, 2(1), 1-14. https://doi.org/DOI: http://dx.doi.org/10.35817/jpu.v2i1.5854

Bušatlić, S., \& Music, A. (2018). The relationship between employees' perception of performance appraisal and work outcomes. Ekonomski Izazovi, 7(13), 17-28. https://doi.org/10.5937/EkoIzazov1813017B

Danish, R. Q., Khan, M. K., Shahid, A. U., Raza, I., \& Humayon, A. A. (2015). Effect of Reward intrinsics on Task Performance of Employees: Mediating Role of Motivation. International Journal of Organizational Leadership, 4(1), 33-46. https://doi.org/10.33844/ijol.2015.60415

Dessler, G. (2003). Manajemen Sumber Daya Manusia. Jakarta: PT Indeks.

Edirisooriya, W. A. (2014). Impact of Rewards on Employee Performance: With Special Reference to ElectriCo . Proceedings of the 3rd International Conference on Management and Economics, (February), 311-318.

Febrianti, S., Musadieq, M. Al, \& Prasetya, A. (2014). Pengaruh Reward Dan Punishment Terhadap Motivasi Kerja Serta Dampaknya Terhadap Kinerja. Jurnal Administrasi Bisnis, 12(1), $1-9$.

Ferdinand, A. (2014). Structural Equation Modeling dalam Penelitian Manajemen (5th ed.). Semarang: Badan Penerbit Universitas Diponegoro.

Gaol, C. H. R. J. L. (2014). A to Z human capital (Ninuk, Ed.). Jakarta: Gramedia Widiasarana Indonesia.

Ghozali, I. (2018). Aplikasi analisis multivariate dengan program IBM SPSS 25 (9th ed.). Semarang: Badan Penerbit Universitas Diponegoro.

Guan, X., \& Frenkel, S. (2019). ow perceptions of training impact employee performance: Evidence from two Chinese manufacturing firms. Personnel Review, 48(1), 163-183. https://doi.org/https://doi.org/10.1108/PR-05-2017-0141

Gusdiana, Ma'aruf, J. J., \& Sulaiman. (2015). Pengaruh Pendidikan dan Pelatihan Teknis terhadap Motivasi Kerja serta Dampaknya terhadap Kinerja Pegawai pada Dinas Perkebunan Aceh. Jurnal Ilmu Manajemen Pasca Sarjana Universitas Syiah Kuala, 4(4), 91-100.

Hasibuan. (2014). Manajemen Sumber Daya Manusia. In Manajemen Sumber Daya Manusia (Revisi). Jakarta: Bumi Aksara.

Januar, R., \& Handayani, D. W. (2015). Pengaruh Ekstrinsik Reward Dan Intrinsik Reward Terhadap Employee Performance : Telaah Pada PT XYZ. Ultima Management, 7(1), 25-38. 


\section{International Journal of Business Management and Economic Review}

Vol. 4, No. 01; 2021

ISSN: 2581-4664

Komalasari, P. T., Nasih, M., \& Prasetio, T. (2009). Pengaruh Public Service Motivation, dan Organizational Citizenship Behavior Terhadap Kinerja Organisasi Pemerintahan. Jurnal Manajemen Teori Dan Terapan, 2(2), 128-141.

Kurniawan, D., Lubis, A. R., \& Adam, M. (2012). Pengaruh budaya kerja dan motivasi kerja terhadap kinerja karyawan International Federation Red Cross (IFRC) Banda Aceh. Jurnal Manajemen, 1(1), 132-146.

Mangkunegara, A. P. (2013). Manajemen Sumber Daya Manusia Perusahaan. Bandung: Remaja Rosdakarya.

Mangkunegara, A. P., \& Waris, A. (2015). Effect of training, competence and discipline on employee performance in company (case study in PT. Asuransi Bangun Askrida). ProcediaSocial and Behavioral Sciences, 211, 1240-1251. https://doi.org/https://doi.org/10.1016/j.sbspro.2015.11.165

Maslow, A. H. (1943). A Theory of Human Motivation. Psychological Review, 50, 370-396.

Mathis, R. L., \& Jackson, J. H. (2011). Human Resource Management: Essential Perspectives (6th ed.). USA: Cengage Learning.

Muchlis, Amri, \& Majid, M. S. A. (2017). Pengaruh Pengembangan Karir, Penempatan, Motivasi Dan Lingkungan Kerja Terhadap Kinerja Pegawai Dan Dampaknya Pada Kinerja Dinas Pendidikan Aceh. Jurnal Manajemen Dan Inovasi, 8(2), 35-50. https://doi.org/https://doi.org/10.24815/jmi.v8i2.9345

Munir, R., Lodhi, M. E., Sabir, H. M., \& Khan, N. (2016). Impact of Rewards (Intrinsic and Extrinsic) on Employee Performance with Special Reference to Courier Companies of Faisalabad City. European Journal of Business and Management, 8(25), 88-97.

Nawawi, H. (2011). Manajemen Sumber Daya Manusia Untuk Bisnis Yang Kompetitif. Yogyakarta: Gadjah Mada University Press.

Nuraini, B. (2014). The Management Of Human Resource Development In Ar Raihan Bandar Lampung Junior High School. Indonesian Journal of Educational Review (IJER), 1(2), 89-94.

Nzuve, S. N. M., \& Njambi, M. P. (2015). Factors Perceived To Influence Employees' Performance: A Case Of The Independent Electoral And Boundaries Commission. Problems of Management In The 21st Century, 10(2), 88-99.

Özkeser, B. (2019). Impact of training on employee motivation in human resources management. Procedia Computer Science, 158, 802-810. https://doi.org/10.1016/j.procs.2019.09.117

Pushpakumari, M. D. (2008). The Impact of Job Satisfaction on Job Performance : An Empirical Analysis. City Forum, 9(1), 89-105. Retrieved from http://202.11.2.113/SEBM/ronso/no9_1/08_PUSHPAKUMARI.pdf

Rachmawati, R. W. (2016). Pengaruh Pelatihan Dan Motivasi Kerja Terhadap Kinerja Karyawan PT. Bank Bjb Kantor Cabang Suci Bandung. Jurnal Manajemen Dan Pemasaran Jasa, 9(1), 116. https://doi.org/http://dx.doi.org/10.25105/jmpj.v9i1.802

Rakhmat, J. (1999). Psikologi Komunikasi. (revised). Bandung: Remaja Rosdakarya. 


\section{International Journal of Business Management and Economic Review}

Vol. 4, No. 01; 2021

ISSN: 2581-4664

Robbins, S. P., \& Judge, T. A. (2017). Essential of Organisational Behaviour (14th ed.). New Jersey: Pearson.

Simamora, H. (2004). Manajemen Sumber Daya Manusia (Edisi III). Jakarta: STIE YKPN.

Sobel, M. E. (1982). Asymptotic Confidence Intervals for Indirect Effects in Structural Equation Models. Sociological Methodology, 13, 290-321. https://doi.org/https://doi.org/10.2307/270723

Sunardi, Adam, M., \& Putra, T. R. I. (2020). Intrinsic Motivation And Personal Value In Predicting The Job Satisfaction And Employee Performance: Study In Marine And Fisheries Department Of Aceh Jaya. International Journal of Business Management and Economic Review, 3(1), 7-16. https://doi.org/http://doi.org/10.35409/IJBMER.2020.3134

Susanty, A., \& Miradipta, R. (2013). Employee's Job Performance: The Effect of Attitude toward Works, Organizational Commitment, and Job Satisfaction. Jurnal Keilmuan Dan Aplikasi Teknik Industri, 15(1), 13-24. https://doi.org/https://doi.org/10.9744/jti.15.1.13-24

Umar, A. (2015). The Effect of Motivation and Career Development Against Employeesâ $€^{\mathrm{TM}}$ Performance and Job Satisfaction of the Governor Office South Sulawesi Province, Indonesia. International Journal of Management Sciences, Research Academy of Social Sciences, 5(9), 628-638.

Umar, H. (2008). Metode Penelitian untuk Skripsi dan Tesis (Ed. Kedua). Depok: RajaGrafindo Persada.

Yuniarsih, T., \& Suwatno. (2016). Manajemen sumber daya manusia. Bandung: Alfabeta. 